\title{
Public Traces in Pre-Revolutionary France: Trivets of the Public Sphere
}

\author{
Fransız Devrimi Öncesinde Toplumun İzleri: Kamusal Alanın Sac Ayakları
}

Özge Aslanmirza*

Kocaeli University, Faculty of Arts and Science, History Department, Kocaeli, Turkey

\begin{abstract}
Examination of the mechanism of the changes in history demands to propagate into the formations in the background. Considering the political, social and structural transformations, the atmosphere in Prerevolutionary France provides a good example for the people's development under these formations which exert influence on the public sphere through freemasonry, salons, and academia. These formations can be discerned as heuristic tools through which people produce new ideas and exchange these thoughts in an intellectual environment. In light of these, the purpose of this study is to present three tenets of the public sphere in 18th century France: freemasonry, salons, and academia. As these three components correspond to the formation of a public opinion and public sphere; freemasonry, salons, and academia can be regarded as the nucleus of extensive freedom of thought and sharing. Thus, this article will display the dynamics of these three trivets and reveal how they contribute to the intellectual mindset of society.
\end{abstract}

Keywords: $18^{\text {th }}$ Century France, Academia, Public Sphere, The French Revolution, Heuristic Tools.
Öz

Tarihteki değişim mekanizmalarını incelemek, arka plandaki oluşumları da irdelemeyi gerektirmektedir. Fransız Devrimi öncesinde Fransız'daki gelişimleri anlamak adına masonluk, salon ve akademi gibi insanların zihni gelişimlerine katkıda bulunduğu düşünülen kamusal alanların oluşumuna dair iyi bir örnek olmuştur. Bu yapılar keşifsel araçlar olarak görülebilir ki insanlar entelektüel bir ortam içinde yeni düşünce oluşumlarına katkıda bulunmuş ve bu düşünceleri birbirleriyle paylaşma olanağı elde etmiştir. Bunların ışığında, bu çalışma, 18. yüzyıl Fransasında kamusal alanı etkileyen üç önemli ayağa, masonluk, salon ve akademiye insanların nasıl düşüneceklerini keşfetmelerine katkıda bulunan bir keşifsel alan olarak bakmayı ve incelemeyi amaçlamıştır. Bu alanların dinamikleri de incelenerek, belirli bir kesimin toplumsal düşünceyi nasıl şekillendirdiği ve Fransız Devrimi öncesindeki zihni atmosferi nasıl biçimlendirdiği ve önayak olduğu ortaya konacaktır. Hem kamusal düşunce hem de kamusal alanın oluşumunda etkili olan bu oluşumların düşünce özgürlüğü ve düşüncenin dolaşımına da etkide bulunduğu düşüncesiyle, bu oluşumların toplumsal zihniyete ve entelektüel hazineye nasıl katkıda bulunduğu ortaya çıkarılacaktır.

Anahtar Kelimeler: 18. Yüzyıl Fransa, Akademi, Kamusal Alan, Fransız Devrimi, Keşifsel Araçlar. 


\section{Introduction}

There are a plethora of articles and books on the Revolution in France and its underlying factors all of which had a purpose to shed light on this milestone in the history of France in social, political and cultural perspectives. For instance, proceeding from recent to previous one, Colin Jones, brilliant scholar on the history of France, examines the political history of 18th century France in his book The Great Nation: France from Louis XV to Napoleon 1715-99, particularly the years between 1715 and 1799 which was ignored by most of the scholars. He reexamines the traditional approach of Ancien Régime and insists on investigating the developments, weaknesses and strengths of France which took place in the "glorious" period of France before the Revolution. In addition, he criticizes the teleological understanding of French Revolution. On the other hand, one-to-one observer of the French Revolution, Alexis de Tocqueville (d. 1859), who was a French philosopher and politician, provided well-articulated and insightful comments on the reasons of French Revolution. He argued that contrary to common belief, the French Revolution did not aim to destroy the prevailing religious beliefs, nor it had an effort to extend disorder to the society. The intention was to set the stage for public authority and create a more uniform and simpler social and political regime based upon social equality (de Tocqueville, 2008). François Furet, on the other hand, criticized the insufficiency of Tocqueville's analysis in terms of the reasons of French Revolution since he thought that Tocqueville's analysis was lack of "sociological conditions" (Furet, 1989, p. 39). In Furet's perspective, political conditions were attached to the subjects, their composition of groups and their relations with the power all of which is related to political sociability. Then, he mentioned the transformation in the world of political sociability beyond the monarchy where the individual came to forefront. He expressed that people garnered in cafes, salons or Masonic lodges to utter their opinions and, by this way, they composed and revealed the public opinion (Furet, 1989).

Overall, they all mentioned the public spheres in the composition of a "public" more or less, however, the concept of "public sphere" deemed a much more in-depth discussion. In this point, Jürgen Habermas and Keith Michael Baker came to forefront. Although their opinions established on divergent points for the function and the extent on the public sphere, Jurgen Habermas and Keith Baker proposed the most prevalent and pivotal arguments on the topic. Firstly, Habermas took a sociologically referent stance as to the concept of public sphere by elaborating on a variety of places where the public opinions raised in the pre-Revolutionary period in the $18^{\text {th }}$ century France by regarding the public sphere as a type of bridge connecting old and new. By blending his reference to the original meaning of the public sphere and its reflections on the contemporary world, for him, the public sphere was "a part of civil society" of which "came into existence as the corollary of a depersonalized state authority" (Habermas, 1991, pp. 3, 19). Yet, this sphere was not the product of "any particular political system" (Nathans, 1990, p. 621). The public sphere, then became a place where "the mutual willingness to accept the given roles and simultaneously to suspend their reality was based on the justifiable trust that within the public" (Habermas, 1991, p. 131). Therefore, people shared and discussed their opinions in an egalitarian way. As a result, they composed their own communities or groups to freely circulate their thoughts. In this perspective, salons and other societies generated the centers of critical discussion, respectively, literary and artistic works and the public policy of the state (Nathans, 1990). Moreover, he highlighted the mingling of the bourgeois intelligentsia with the nobility. He argued that at the outset, bourgeois public sphere made itself attainable to the different layers of society through social groups, as a consequence, public sphere broadened and encompassed the "public". Hence, it became a tool between the state and the society (Nathans, 1990).

On the other side, Baker put emphasis on a political ground while examining the public sphere. Setting his arguments on the basis of public opinion together with the public sphere, Baker (1990) defined public sphere "in which the nation could reclaim its rights against the crown" and he adds that through this space the French Revolution became conceivable since this space offered a new political space (p. 199). In addition, he mentioned a discursive construct of the public opinion in which challenges the role of the state and its deeds. 
While analyzing the public opinion and sphere, one of eminent aspects of his arguments was his structure where he blended the not only the canonical texts but also the lesser-known ones to reveal broader contexts (Maza, 1993). Both sociological indications and political considerations are actually blended in considering the freemasonary, salons and academia as they not only serve the enlightenment of the people by serving the discovery but also become a preparation ground of the political changes as in the case of French Revolution. These three trivets are regarded as heuristic tools in the scope of the article because heuristic, which means "serving to find out" (Oxford University Press, 1996, p. 215) inherently associated with the knowledge exchange in freemasonary, salons and academia where people come together to interchange their ideas and learn from each other influencing their way of thinking, as well. The heuristics is benefitted from wide range of academic fields. Highlighting the Polya's (2004) statements, heuristics aspires to "a better understanding of the mental operations" (p. 132). Although he puts forth the purpose of the heuristics in a different context, his point is sustainable as it will be convenient tool to understand the mechanism of these three formations in which the change in the mental process of the people begins to be observed in the eve of French Revolution.

Above all, the fundamental aim of this paper is to present three tenets of the public sphere in $18^{\text {th }}$ century France: freemasonary, salons and academia. Indeed, they are important components of the society of preRevolutionary France as heuristic tools since they were the nucleus of enlightening and improving society and their seal of intelligence can be considered as "being a torch" against the restriction of the freedom of mind, namely, the monarch and the clerical understanding of the Church. Thus, this paper will demonstrate how freemasonry, academia and salons are formed as heuristic tools in the $18^{\text {th }}$ century France.

\subsection{Three Trivets in the Surface: Freemasonry, Salons and Academies}

The freemasonry, salons and academies were the main centres of the circulation of knowledge. It has to be kept in mind that the status of the people in these circles are not ordinary citizens, but the elites who were also pioneered and impacted the society composing the educated and enlightened part. In one way or another, directly or indirectly they were determinant factors in the nucleus of a new generation on the process and the eve of French Revolution. Indeed, their degree of relation into the politics is still a going debate, however, they are deeply influential in steering the period's context. For instance, as Kenneth Loiselle (2014) states "Freemasonries did not merely represent a space where a distinct form of political culture anchored in elections and following written laws, could take hold- actual talking about actual politics could and did occur within the lodge" (p. 236). Salons created a space of socialization between men and women, not excluding the politics, political decisions, and events (Kale, 2004). Academies serves to the seeds of the future lineage by offering an official instruction. Considering their particular role, they propagated into the mentality of the society and they were influential in the fate of the French politics.

\subsubsection{Freemasonary}

Freemasonry groups, aside for being a highly cultured aspects of the members, might be the vaguest groups among the diverse sphere due to their secrecy where the members where the members swore an oath in order not to give away the mysteries of their order, and they regularly referred to non-members of their group as the "profane" (Melton, 2001, p. 253). In the atmosphere of $18^{\text {th }}$ century France, freemasonry attributed an importance in which the members established a new form of individual power by involving in the governmental issues through an opponent stance (Jacob, 1991). The freemasonry groups were the social mixing places where the member of it get title and status. The group was both skeptical and useful category of analysis for the scope of pre-Revolutionary France through their deeds and aims. The members of the freemasonry had the ideal understanding of the world with their intentions and activities. For them, they bound to each other with the link of brotherhood with all of their members with the aim of being the "model subjects" for the people by being exemplary citizens who brought light to the world with the knowledge and hard work (Beaurepaire, 2006, p. 409). 
As a part of developing intellectual sociability, the first masonic lodge was opened in 1721 and the first Parisian one was in 1725 or 1726, afterwards they were spread quickly throughout the urban space (Jones, 2014). Some early studies, however, suggests that freemasonry was not that widespread in the aforementioned time span, asserting that, out of the département of the Seine (where there were some 4,000 masons which belonged to sixty-one lodges), there were some 10,000 paid-up masons as the members to the 187 lodges of the GrandOrient de France, being the highly populated one (Wright, 1991). For Colin Jones (2002), their rapid growth ended up with their being organized under the Grant Orient of France, at the end of $18^{\text {th }}$ century "as many as 1,000 lodges throughout France containing between 50,000 and 100,000" masons (p. 367).

Their inner structure was close to a democratic set-up. In their hierarchy, there were degrees according to their experience and knowledge, however, their concept of "brotherhood" enabled them to overcome the obstacle of a strict hierarchy in which they abolished the status among them. That could be the reason why they could provide a milieu by generating their constitutions and election as if they were a microscale of a democratic system. Yet, their inherent democracy was open to discussion in the sense that the members of the freemasonry could be significantly aristocratic, also, although they were claimed to have been equal among each other, they blamed to have copied the social hierarchy in the French society (Jacob, 1991). The reason was that the members were not integrated into their own hierarchy according to their birth-based status in the society but based on their merit. On the other hand, James Van Horn Melton (2001) stated that their structure -albeit egalitarian- and secrecy resembled to the "absolutist political culture" which considered that politics could only be understood by certain, privileged few, in addition, he challenged this argument by asserting that masons were both trying to protect the esoteric knowledge they had and composed a zone of autonomy against the state and its institutions (p. 253).

Even though freemasons seemed to be naïve and well-meant, the monarchy was suspicious about their blurred political existence. It is known that the Cardinal Fleury, cardinal and the chief minister of Louis XV, was against their rituals finding it them irreligious, also, their secrecy and aristocratic membership (Jones, 2014). Their stance seemed to have been a threat both to the monarchy and the Church. Actually, there were other assumptions which claims that the members of freemasonry rarely looked for local power or the governance. Furthermore, the representatives of the monarch and the institutions of local power seemed to have been interested in the French lodges by the 1770's, nevertheless, after that time, the French Grand Lodge search for having a public presence in Paris by becoming near to the government to diminish suspicions directed to them (Burke \& Jacob, 1996). Particularly the French authorities were suspicious about the Freemasons as "their rituals made them look like a new religion and because they had attracted aristocratic membership" (Jacob, 2019 , p. 22). Overall, it seems that they were active in the generation of the environment where the members of the freemasonry provided a self-enclosed model of the civilized and participant sphere before the French Revolution.

\subsubsection{Salons}

Salons can be regarded as one of the major institutions in the French society in terms of its vivid structure and hosting of leading characters of the $18^{\text {th }}$ century France. By providing a social and intellectual milieu, they were the place where the attendants garnered around the intellectual discourse in which they experienced the art of conversation than having a conversation. Besides, they were the socially blended zones where social elites merged with the artists, musicians and the writers of the Enlightenment (Jones, 2014). In the first place, it has long been argued that women played a significant role as the host of salons in a male-dominated society. Thus, these salons became tool of women integration into the intellectual sphere (Outram, 2013). They were deciding who would attend the meeting, who would be invited, and which topics could be discussed, also, took part as the discursive agents of the conversations. As different from the other components of the public sphere such as coffeehouses where there were nonexistent patrons of salons ended up with being more egalitarian (Calhoun, 2012). 
On the other hand, as contrary to widespread arguments related to salons, Antoine Lilti's approach to the salons is quite a challenging one since he revisits the imagination of the salons. To begin with, he is extremely critical about the well-defined, concrete existence of the salons as a cultural institution (Caradonna, 2006). Caradonna (2006) conveys from the book by stating that the term salon (salonnière in French) is the invention of the $19^{\text {th }}$ century, thus, $18^{\text {th }}$ century had no concept of salon in the first place (p. 2). Therefore, attribution to salon as a miniature Republican environment or any other denotation was not that useful, even, he went further by asserting that it was an anachronistic perspective to look at salons as well-defined establishments.

Secondly, Lilti challenged the fact that salons were the tool of feminization the Republic of Letters which was particularly put forth by Dena Goodman. For Lilti, the appearance of women in the salon went back to the "tradition of aristocratic hospitality" in which women, as a hostess of the house, had a role to play and they were not actively involving intellectual discussions among men. He highlights that women who had a wish to publish books, wanted to be noted as authors, scholars, or poets were disentitled in the salon environment, and even, they humiliated as "femmes savantes" (Caradonna, 2006, p. 10). Thus, as Steven Kale (2002) argued, it would be better to think salons as "mixed-sex gathering than as a vehicle for the empowerment or emancipation of women" (p. 137).

Building on her own arguments, she mentioned how the Republic of Letters (intellectual community) would be challenged as to the public sphere. Firstly, she argued that the term public sphere should be reconsidered since she thought that this cannel became the public utility of the intellectual community. Secondly, she related this situation to the aim of "nationalization" where she highlighted the fact that intellectual innovations and their flow in the society were proceeded and monitored by national institutions often, however, the desire of "political social elites" were ample for manipulating this fashion in the context of national projects (Lilti, 2009, p. 11). For him, the Republic of Letters was not a suitable concept for salons to name suggesting that worldliness was much more fitting since referred to an interaction among "court society, elite networks, and the literary sphere" (Lilti, 2009, p. 11).

Beyond the contested arguments about the salons, it was a fact that their existence as a part of public sphere in which they manifested themselves as the centers where people felt pulse of intelligentsia of that time. In their elite and attractive atmosphere, the certain features of the salons made them a tool of brainstorming and discussion. One of the prominent examples of the salon of the $18^{\text {th }}$ century was the Holbach's house due its attendants and the atmosphere. The hospitability of Holbach and his wife created a comfortable and open place of discussion where people exchanged their ideas, "debate philosophical and scientific questions, read and criticize new work" (Blom, 2010, p. 8). Their quests were quite impressive, to name some of them: Denis Diderot, Voltaire, Rousseau and d'Alembert who were claimed to pave the way for the path of Revolution with their brainstorms where the news and enlightened ideas were flourished. The salon of d'Holbach was open to these kinds of rumors. For example, some claims were that the members of the salons were planning the French Revolution while they were appearing to discuss economics, some others claimed that they were running a factory where they were publishing illegal books which had a purpose to influence people to overthrow monarchy (Blom, 2010). In addition, for Blom, the salient attendants of the salons were literally forming revolutionary ideas or overthrowing the Catholic Church, nevertheless, it was much more than a political revolution they proceeded, and the most significant deed was writing, publishing seditious books through which, people would not have a fear of oppression and fall into the trap of ignorance irrespective of gender and live their lives fully (Blom, 2010).

Despite the controversial stance of the salons in the $18^{\text {th }}$ century France, namely, their being a nest of forward looking ideas all of which produced in the discussions, conversations and the contributions of different thinkers such as Diderot, Voltaire, Rousseau and many more, also, the idea of salons in which people gathered around social and cultural domination through literature: generating and uttering poetry, playing witty games, performing theatrical performances (Lilti, 2009), they expressed a lot about the gender, the manner of polity 
and sociability. No matter what, salons were the active environment of exchanging clashing and conflicting ideas if the literary devices could be thought of an expression of ideas blended and furnished with the period's political turmoil.

\subsubsection{Academies}

Academies are key institution in $18^{\text {th }}$ century France composing of diverse social components. They both preserved the "cultural justification for the monarchy" and contributed to the generation of a new elite which was also against the hierarchy with egalitarian aims (Knight, 1979, p. 766). In Daniel Roche's interpretation, the academies provided a balance in a culture which is full of stress because they were in-between the innovation and the tradition (Knight, 1979). Particularly, local elites got together for brainstorming and they granted award for the essays on certain topics in the provincial academies which encouraged prospective scholars to involved in the education process (Maza, 1993). Roger Chartier (1991) mentioned academies, along with the salons, as the place where the thoroughgoing definition of humanism shattered and the distinction of litteratur and the scholar became visible (p. 59). For example, they were the center of science and art, especially, Royal Society and Paris Academy were the most progressive and up-to-date ones (McClellan, 1985). They were greatly influenced by the Renaissance academies in terms of organizational structure. Hence, there was an active environment of learning and it was not restricted to the individual but a collective one.

The academies, in time, began to contribute to the local learning or "enlightening" process to the urban milieu by being a transmitter of knowledge through libraries which carried knowledge to the public. For example, they were important representatives in process of providing access to the traditional libraries in $18^{\text {th }}$ century and made them to become widespread (Melton, 2001). Actually, the Enlightenment writers highly condemned the "representational function of princely and aristocratic libraries" and they drew attention to the fact that libraries should have been open to public readers (Melton, 2001, p. 105). These criticisms raised awareness and the libraries of provincial academies in France, commenced to open their sources to the use of public reader, even, the libraries of the academies in Bordeaux, Pau, La Rochelle, and Nancy shared their collections to the readers two or three days a week in the 1730's and 1740's (Melton, 2001).

Although they were educating a generation who were knowledgeable and who were going through a scientific education, the newly developed free schools which also aimed to provide scientific education, however, different from the provincial academies, they were trying to fuse the sciences and the arts to carry technical and practical knowledge to the general, working class public by opening new programs (McClellan, 1985). Apart from that, academies were too rigidly integrated themselves into the locality enjoying themselves with the privileges, however, they began to have been not flexible enough to compensate the needs of the society they lived in at the latter part of the $18^{\text {th }}$ century (McClellan, 1985). Yet, they were the institutions which laid the ground for Enlightenment and the progressive thought.

\section{Conclusion}

Behind every convulsive incident in history, there are opinions which are shaped by the prudent minds in specific times within the certain places. The revolutionary ideas of these minds can only be generated through a milieu that remove the pressure on the liberating mind, provide both an amiable place enough for one to express ideas freely and challenging enough to clash variety of ideas which gives birth to commutative thoughts. For French Revolution, this kind of sphere was not a single one, however, it ranged from coffee houses to salons. Yet, salons, academies and freemasonry groups can be regarded as the trivets of the public sphere in the $18^{\text {th }}$ century France. Even though they are dissimilar to each other in terms of their composition and structure they can be considered as the heuristic tools of the pre-Revolutionary Era in $18^{\text {th }}$ century France in which people stimulate their own awareness and wisdom. 
A close analysis to these trivets reveals important characteristics which are subjected to the studies related to the emergence of public sphere. Habermas highlights their sociologically nature of the public sphere in which people partake in commensurably and freely express their opinions. Fundamentally, this kind of public sphere excludes the state from its boundaries adding that salons, for instance, for him, was an apolitical place where people were educating themselves in the way of critical public comments and came to be a bridge between the "collapsing" "courtly-noble society" and "the bourgeois public sphere" (Habermas, 1991, p. 30).

Yet, his arguments paved the way for the discussions on public sphere with contesting ideas. Michael Baker, for instance, located public sphere into a political ground where these places not only enabled people to express their opinions freely but also turned into an action place against the existent monarchy. Sarah Maza, extended this argument by highlighting the public sphere as a triggering factor for the French Revolution. Among all the diverse comments on public sphere, then, how can we situate and interpret the freemasonry, academies and salons?

Inherently, these trivets were highly complementary to each other with their specific aspects with different roots but similar aims on the way of training and creating a fairer and egalitarian society. For instance, although academies and freemasonaries remained male-dominated in the pre-Revolutionary period in France, the salons were the places where women integrated themselves into this sphere by being the hostess of these intellectual environment (although their active involvement into the intellectual discussion was discussable). They are all claimed to be or tried to be egalitarian in their nature. They were places where people express their opinions in relative freedom. They had an effort to make France a place where people embraced freedom without the pressure of monarchy or the church by being respectful to people's thought, religion and other dynamics that made them human. Yet, these kinds of places were not away from the political thoughts or the policies of their time. Although Habermas approached this issue with his sociological base and Baker put emphasis on the political references, it could be more than that. Colin Jones (2002), for instance, argues that there was a bourgeoisie public sphere as claimed by Habermas, nonetheless, he put emphasis on the role "in opening up new spaces for cultural and political exchange ... before 1789 , these new spaces were invaded by pre-existing political actors and provided venue for existing debates" (p. xxv). Thus, he draws attention to a public sphere which had already generated through the existing polity largely inherited by the Bourbon polity (Jones, 2002a). In that sense, Jones frames a public sphere which is not developed independent from the ongoing politics but a dependent one. In 1787-8, the protests which were ushered by the parlement and the wave of support from the public sphere could be an important example of how the public sphere and the polity is mingled with each other, closely.

Last but not the least, the understanding of the ruptures in history, as in the case of French Revolution, requires the wholistic apprehension of the social dynamics intermingled with the broader political contexts. Besides, it needs certain tools which helped historians to reveal these changing dynamics or the composition of these dynamics. In this paper, salons, academies and freemasonries served this aim. They are salient components not only for the pure "public" sphere, but also a public sphere taken its roots and inspiration from the political setting of the $18^{\text {th }}$ century France. Without their voice, it could be impossible to grasp the nucleus of the Enlightenment idea, too, with their effects on the way to the French Revolution which was deemed by most of all intellectual members of the society hand in hand with the public but ended up with being the Reign of Terror.

\section{References}

Baker, K. M. (1990). Inventing the French Revolution: Essays on French political culture in the eighteenth century. Cambridge University Press. https://doi.org/10.1017/CBO9780511625527.

Beaurepaire, P. Y. (2006). The universal republic of the freemasons and the culture of mobility in the enlightenment. French Historical Studies, 29(3), 407-431. https://doi.org/10.1215/00161071-2006-005.

Blom, P. (2010). A wicked company: The forgotten radicalism of the European enlightenment. Basic Books. 
Burke, J. M. \& Jacob, M. C. (1996). French freemasonry, women, and feminist scholarship. The Journal of Modern History, 68(3), 513- 549. https://doi.org/10.1086/245341.

Calhoun, B. (2012). Shaping the public sphere: English coffeehouses and French salons and the age of the enlightenment. Colgate Academic Review, 3(1).

Caradonna, J. L. (2006). Review of Antoine Lilti's Le monde des salons: Sociabilité et mondanité à Paris

au au XVIIIe siècle, by Antoine Lilti. Jeremy Caradonna. https://www.jeremycaradonna.com/Review\%20of\%20Antoine\%20Lilti.pdf Chartier, R. (1991). The cultural origins of the French revolution. (L. G. Cochrane, Trans.). Duke University Press.

de Tocqueville, A. (2008). The ancien régime and the French Revolution. (G. Bevan, Trans.). Penguin Books.

Furet, F. (1989). Interpreting the French Revolution. (E. Forster, Trans.). Cambridge University Press.

Habermas, J. (1991). The structural transformation of the public sphere: An inquiry into a category of bourgeois society. (T. Burger $\&$ F. Lawrence, Trans.). MIT Press.

Jacob, M.C. (1991). Living the enlightenment: Freemasonry and politics in eighteenth-century Europe. Oxford University Press.

Jacob, M. C. (2019). The secular enlightenment. Princeton University Press.

Jones, C. (2002). The great nation: France from Louis XV to Napoleon 1715-99. Columbia University Press.

Jones, C. (2014). The smile revolution in $18^{\text {th }}$ century Paris. Oxford University Press.

Kale, S. D. (2002). Women, the public sphere, and the persistence of salons. French Historical Studies, 25(1), 115-148. https://doi.org/10.1215/00161071-25-1-115.

Kale, S. D. (2004). French salons: High society and political sociability from the old regime to the revolution of 1848 . The Johns Hopkins University Press.

Knight, I. F. (1979). [Review of the book Le siecle des Lumieres en Province: Academies et Academiciens Provinciaux, 1680-1789 by D. Roche]. The American Historical Review, 84(3). http://dx.doi.org/10.2307/1855483.

Lilti, A. (2009). The kingdom of politesse: Salons and the republic of letters in eighteenth-century Paris. Republics of Letters: A Journal for the Study of Knowledge, Politics, and the Arts, 1(1), 1-11.

Loiselle, K. (2004). Brotherly love: Freemasonry and male friendship in enlightenment France. Cornell University Press.

Maza, S. (1993). Private lives and public affairs: The causes célèbres of prerevolutionary France. University of California Press.

McClellan, J. E. (1985). Science reorganized: Scientific societies in the eighteenth century. Columbia University Press.

Melton, J. H. (2001). The rise of the public in enlightenment Europe (New approaches to European history). Cambridge University Press.

Nathans, B. (1990). Habermas's 'public sphere' in the era of the French revolution. French Historical Studies, 16(3), 620-644. https://doi.org/10.2307/286491.

Outram, D. (2013). The enlightenment. Cambridge University Press.

Oxford University Press. (1996). Heuristic. In The concise Oxford dictionary of English etymology (1st ed., p. 215).

Polya, G. (2004). How to solve it: A new aspect of mathematical method. Princeton University Press.

Wright, V. (1991). "Les Frères en Lutte"? provincial freemasonry on the eve of the third republic. French Politics and Society, 9(2), $39-52$. 